\title{
Geochemical Analysis of Lilida geothermal spring
}

\author{
Basile Belanganayi ${ }^{1}$ LUSE, Augustin Monga MAKONGA ${ }^{2}$
}

Manuscrit reçu le 21 avril 2018 et accepté le 6 juin 2018

\begin{abstract}
Departments of Geology and Geochemistry; Faculty of Science; State University of Ruwenzori (Université Officielle de Ruwenzori), B.P.560, Butembo city, North-Kivu, DR Congo.
\end{abstract}

\section{Résumé}

Une étude géochimique a été effectuée sur l'eau d'une source géothermale appelé Lilida, située dans la province de l'Ituri, dans la partie nord-est de de la République Démocratique du Congo. Ses objectifs étaient de définir le faciès chimique de ladite eau, de déterminer la nature lithologique de son réservoir et d'estimer la température qu'elle possède dans son réservoir. Les échantillons d'eau ont été prélevés au mois de février de l'année 2017 et soumis à des analyses chimiques et physiques. En plus, les diagrammes de D'Amore et al. (1983), de Giggenbach (1991) et de Piper (1944) ont été élaborés pour obtenir la classification de cette eau thermale. Au terme de cette étude, l'eau de la source Lilida s'est révélée du type bicarbonaté calcosodique. Son facies géochimique étant pour les cations $\mathrm{Na}^{+}>\mathrm{Ca}^{2+}>\mathrm{Mg}^{2+}$ et pour les anions $\mathrm{HCO}_{3}^{-}>\mathrm{SO}_{4}^{=}>\mathrm{Cl}^{-}$. Il s'est avéré que son réservoir était une formation argileuse peu profonde contenant certainement des calcaires dolomitiques et des dérivées des flyschs ou « volcanites ». L'application de la géothermométrie a révélé que l'eau étudiée aurait, dans son réservoir, une température de $45,7{ }^{\circ} \mathrm{C}$. En tant que telle, elle ne peut faire objet que d'une exploitation géothermique basse énergie.

Mots clés : Lilida, Ituri, géothermie, faciès chimique, géothermométrie, nature lithologique.

\section{Abstract}

A geochemical survey on the thermal water released by the Lilida Spring, located in the Congolese Northeastern Province of Ituri was undertaken. The aims of this study were to determine the chemical facies of this water; to determine the lithological nature of its reservoir and to predict its subsurface temperature. The water samples were collected in February 2017. Then physical and chemical analyzes were done. The graphics of D'Amore, Giggenbach and Piper were applied on the water analyzes to obtain its classification. The studied water was characterized as a bicarbonated calcosodic shallow fresh groundwater, with this following geochemical facies for the cations $\mathrm{Na}>\mathrm{Ca}>\mathrm{Mg}$ and this one for the anions $\mathrm{HCO}_{3}>\mathrm{SO}_{4}>$ $\mathrm{Cl}$. Its reservoir was characterized as an argillaceous formation containing certainly dolomitic limestone and flysch derivate or «volcanites». Assessments from chemical geothermometer

\footnotetext{
${ }^{1}$ Adresse pour le courrier électronique : lusebasile@gmail.com

${ }^{2}$ Adresse pour le courrier électronique : mongaaugustinm@gmail.com
} 
suggest the existence of a peripheral geothermal reservoir of low enthalpy $\left(45.7{ }^{\circ} \mathrm{C}\right)$. Thus, in that state, this thermal water can only be used for geothermal low energy exploitation.

Keywords: Lilida, Ituri, geothermic, chemical facies, geothermometry, lithological nature.

\section{Introduction}

The geothermal energy appears as an alternative to pollutant energies including fossil and thermic energy because it is relatively none pollutant and has none significant contribution to climate warming. In fact, a geothermal plant produces a few amount of rejection. The quantity of $\mathrm{CO}_{2}$ ejected by all geothermal plants of the world is about $1 / 10$ of what only one gas power station can produce. This amount can be reduced to zero, by injecting the geothermal fluid in the reservoir in which it is from, after its use. This technique is widely used, nowadays (Harsh \& Sukanta, 2007). Otherwise, the geothermal energy owns advantage of being a renewable energy which does not depend on the climate, and is susceptible to be exploited both for thermic and electric energy (Ahmed, 2009), and it is available everywhere. Of course, depending on the structure of geologic formations or the rocks composition, it could easily been extracted from certain regions rather than others. However, the technology susceptible to allow a global development of the geothermal energy exists today.

The East African Rift System (EARS) is one of the greatest tectonic structures of the earth where the geothermal energy escapes from the interior of the earth to the surface. The EARS extends for about $6500 \mathrm{~km}$ from the Middle East (Dead Sea-Jordan Valley) in the North to Mozambique in the South, passing through Eritrea, Djibouti, Ethiopia, Kenya, Tanzania, Uganda, Rwanda, Democratic Republic of Congo (DRC), Zambia, Malawi, Mozambique and Madagascar (Ring, 2014).

Despite the high geothermal potential of the EARS, most countries of that region have not gone beyond the exploration stages and the inventory work of their resource potential.

DRC was the first African country to carry out an exploitation project of geothermal energy. In 1952, a 0,2 MWe binary plant was installed in a hot spring of up to $91{ }^{\circ} \mathrm{C}$, at Kiabukwa in the former Katanga province (presently divided), within the Upemba incipient rift. The plant stopped functioning after a few years due to lack of proper maintenance and to low fluid flow rates. From then on, no other geothermal project has been undertook, despite of the membership of DRC to the African Rift Geothermal Development Facility (ARGEO).

However, DRC possess a large geothermal potential, particularly in some provinces such as South -Kivu, North-Kivu, former Katanga and Central-Congo. The large part of this resource (in form of springs) is located in the Eastern part of the country constituting the Western branch of the East African Rift Valley (Esseqqat, 2011). Although these geothermal springs are susceptible to produce enough electrical and thermic energy to make up for energy lack, that the country is facing, these resources are not well studied. Thus, a national assessment of geothermic potential and a characterization of these springs are deeply needed. This study, focused on Lilida spring, was carried out in this purpose. Its aims were to determine the chemical facies of this water; to determine the lithological nature of its reservoir and to predict its subsurface temperature.

\section{Material and Methods}

\subsection{Study area}

The Lilida geothermal spring is located in the Congolese Northeastern Province of Ituri, Territory of Djugu, between $1^{\circ} 31^{\prime} 44^{\prime \prime} \mathrm{N}$ and $30^{\circ} 31^{\prime} 23^{\prime \prime} \mathrm{E}$ (Figure1). Apart from the alluvial plain of Albert lake located at altitude ranges from 600 to $900 \mathrm{~m}$, the territory is a peneplain with altitude varying between 1000 and $2500 \mathrm{~m}$. The highest peak is located on Aboro (2456 m) and Adjo (2425 m) mountains (Ndjele, 1988). 


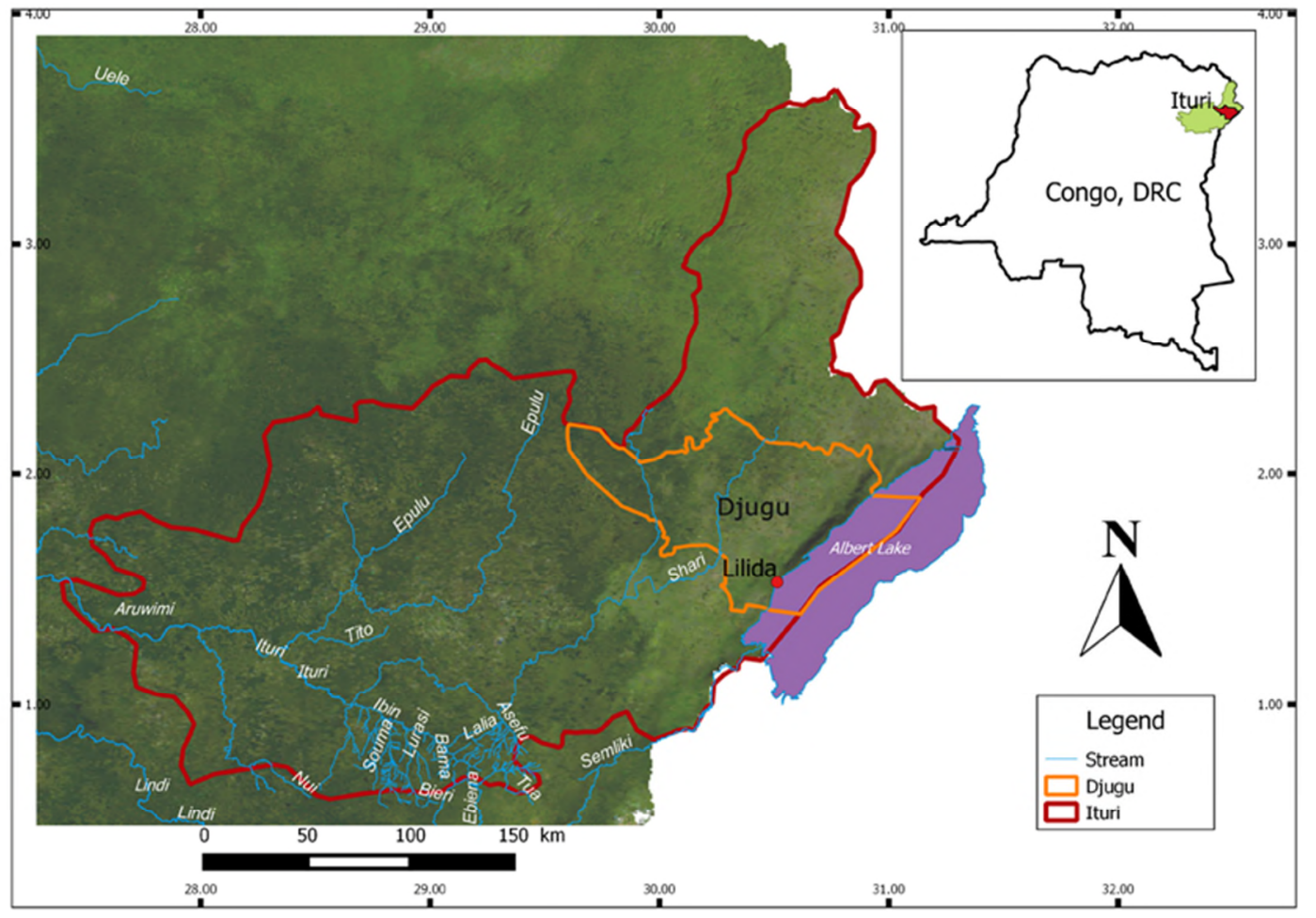

Fig. 1: Location map of study area.

Two types of climate are recognized in the region: a tropical savanna dry climate with a dry season of about 100 days, from December to February ( $\mathrm{A}_{\mathrm{w}}$ in Koppën classification) and a temperate hot climate without dry season $\left(\mathrm{C}_{\mathrm{f}}\right.$ in Koppën classification). The normal rainfall ranges from 1000 to $1400 \mathrm{~m}$ per year. The temperature varies with seasons between 18 and $25^{\circ} \mathrm{C}$. The vegetation in Djugu is dominated by wooded savannas crossed by forest galleries in the East, and by tropical forest in the West (Ndjele, 1988).

The soil of Djugu territory is described as humiferous ferrisol belonging to the sub-order of hydro-xerokaolisols (Sys, 1960). Neighboring the Albertine rift, the Ituri region in which is located the Territory of Djugu could be defined as a complex collapse basin. Three main formations constitute its geology: a substratum of granitoid rocks (dominated by albite $\mathrm{NaAlSi}_{3} \mathrm{O}_{8}$ ); an amphibolite's cover, in normal contact with the preceding and reaching a depth of $400 \mathrm{~m}$ at certain places (in general, those amphibolites are thin and accompanied with green hornblende and feldspar); a superficial layer of Metamorphic rocks which constitute a large region commonly called "Kibali System" or "Kibalian". The Kibalian is in general made of schistoids often carbonated (Woodtli, 1956).

\subsection{Water sampling}

Spring water sampling was conducted during February 2017. Two cleaned 500ml glass bottles were used as samplers and containers. Each bottle was rinsed twice before collecting samples; firstly with distillated water, secondly with the spring water.

\subsection{Chemical and physical analysis}

The geographical location of the spring was determined with a handheld GPS garmin $64 \mathrm{~s}$ worldwide. Temperature was measured in situ using a centigrade thermometer. The $\mathrm{pH}$ was measured using a pH-meter METTLER Toledo; electrical conductivity (EC) with a DiST 3 HI 98303 conductimeter. Total dissolved solid (TDS) was calculated from EC by the empirical formula TDS $=0.7$ EC. Calcium, magnesium, sulfate, chloride, carbonate and bicarbonate were determined by volumetric titration (Skoog $\&$ West, 1969). Flame photometer was used to measure the sodium and potassium. 
To estimate the reservoir temperature of Lilida spring water, we used Na-K geothermometer (Michard, 1979) and Na-K-Ca geothermometer [10] whose equations are respectively:

$$
t^{\circ} \mathrm{C}=\frac{933}{0.9993+\log \left(\frac{N a}{K}\right)}-273.15
$$

Where $\mathrm{Na}$ and $\mathrm{K}$ are concentrations expressed in $\mathrm{mg} / \mathrm{L}$.

$$
t^{\circ} C=\frac{1647}{\log \left(\frac{N a}{K}\right)+\beta \log \left(\frac{\sqrt{C a}}{N a}\right)+2.24}-273.15
$$

Where $\mathrm{Na}, \mathrm{K}$ and $\mathrm{Ca}$ are molar concentrations expressed in mol/L. $\beta=4 / 3$, if the temperature is $<100^{\circ} \mathrm{C}$ and $1 / 3$ if it is $>100{ }^{\circ} \mathrm{C}$. Practically, the following rules apply: calculate firstly the temperature using $\beta=4 / 3$, if the calculated temperature is higher than $100{ }^{\circ} \mathrm{C}$, resume calculation using $\beta=1 / 3$. However, if the calculated temperature is lower than $100{ }^{\circ} \mathrm{C}$, it means that $\beta=4 / 3$ gives an appropriate estimation of reservoir temperature.

Although the Na-K-Ca geothermometer was formulated by Fournier and Truesdell (Fournier \& Truesdell, 1973) to account for fluids containing relatively high calcium which give an anomalously high temperature using the Na-K geothermometer, it is susceptible to undergo correction. We used the method formulated by Fournier and Potter II (Fournier \& Potter II, 1979) which consists in calculating parameter $\mathrm{R}$ :

$$
R=\frac{M g}{M g+C a+K} \times 100
$$

Where $\mathrm{Mg}, \mathrm{Ca}$ and $\mathrm{K}$ are concentrations expressed in equivalents/L.

If $\mathrm{R}>50$, admit that water origins from a shallow aquifer and has a temperature surrounding the surface temperature. Thus, do not take into account the temperature calculated by means of the geothermometer. On the contrary, if $\mathrm{R}<50$ and the Na-K-Ca temperature $>70^{\circ} \mathrm{C}$, use abacuses to determine $\Delta \mathrm{t}^{\circ}(\mathrm{Mg})$ which is the value to subtract to the Na-K-Ca temperature to obtain the estimated temperature. The abacus we used is given in figure 2 .

To determine the chemical facies of Lilida Spring water, a diagram of Piper was created using the analytical data obtained from the hydrochemical analyzes. In general, the sample points are classified in the piper diagram into six fields. They are: $1 . \mathrm{Ca}-\mathrm{HCO}_{3}$ type, 2. Na-Cl type, 3. Ca-Mg-Cl type, 4. Ca-Na$\mathrm{HCO}_{3}$ type, $5 . \mathrm{Ca}-\mathrm{SO}_{4}$ or $\mathrm{Ca}-\mathrm{Cl}$ type $6 . \mathrm{Na}-\mathrm{HCO}_{3}$ type.

The ternary diagram $\left(\mathrm{Cl}-\mathrm{SO}_{4}-\mathrm{HCO}_{3}\right)$ of Giggenbach (1991) was plotted to classify Lilida spring water. Using it, several types of thermal water can be distinguished: mature waters, peripheral waters, steam heated waters and volcanic waters. 


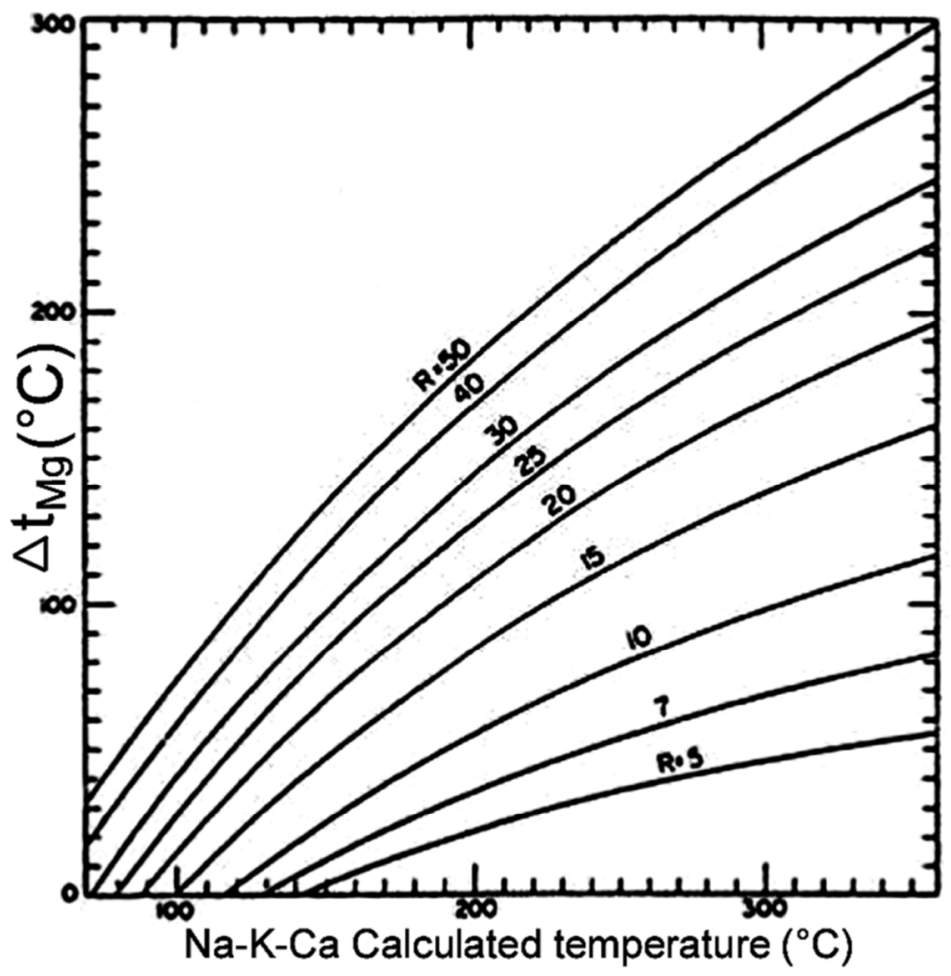

Fig. 2: Plot for estimation of the $\Delta \mathrm{t}(\mathrm{Mg})$ correction to apply to $\mathrm{Na}-\mathrm{K}-\mathrm{Ca}$ temperature for $5<\mathrm{R}<50$.

The plot of D'Amore et al. (1983) was created (using MS Excel spreadsheet) to determine the lithological nature of the Lilida spring water reservoir. This method consists in calculating and plotting six parameters (A, B, C, D, E et F) whose values vary between -100 and +100 , from principal ions contents (in $\mathrm{meq} / \mathrm{L}$ ), the sum of cations contents $\Sigma(+)$ and the sum of anions contents $\Sigma(-)$. Then, the obtained plot is compared with the four reference plots $(\alpha, \beta, \gamma$ and $\delta)$ of D'Amore et al. (1983).

These parameters are:

$$
A=100 \times \frac{\mathrm{HCO}_{3}-\mathrm{SO}_{4}}{\Sigma(-)}
$$

This parameter allows distinguishing waters circulating through calcareous field from these ones crossing evaporative sequence.

$$
B=100 \times\left(\frac{\mathrm{SO}_{4}}{\Sigma(-)}-\frac{N a}{\Sigma(+)}\right)
$$

This parameter allows distinguishing waters enriched by sulfate and circulating in evaporative sequence from those ones enriched by sodium and found in sedimentary clayey-marly field.

$$
C=100 \times\left(\frac{N a}{\Sigma(+)}+\frac{M g}{\Sigma(-)}\right)
$$

This parameter allows distinguishing waters circulating in flyschs field from those ones circulating in carbonated evaporative sequence or from a schist-quartzite basement. Both types of water are sodium-rich but the first group has low chloride content and the second has a $\mathrm{Na} / \mathrm{Cl}$ ratio surrounding 1 .

$$
D=100 \times\left(\frac{N a-M g}{\Sigma(+)}\right)
$$

This parameter characterizes waters having circulated in dolomitic limestone. 
Bulletin de la Société Royale des Sciences de Liège, Vol. 88, Articles, 2019, pp. 44 - 55

$$
E=100 \times\left(\frac{\mathrm{Ca}+\mathrm{Mg}}{\Sigma(+)}-\frac{\mathrm{HCO}_{3}}{\Sigma(-)}\right)
$$

This parameter allows distinguishing waters circulating in carbonated reservoir from those ones circulating in sulfated reservoir.

$$
F=100 \times\left(\frac{C a-N a-K}{\Sigma(+)}\right)
$$

This parameter reveals the growth of potassium content in water.

\section{Results and discussions}

Water quality parameters of the Lilida spring are presented in Table 1.

\begin{tabular}{|c|c|c|}
\hline Category & Parameter & Value \\
\hline \multirow{12}{*}{ Chemical } & $\mathrm{TDS}(\mathrm{mg} / \mathrm{L})$ & 427 \\
\hline & Alkalinity (mg/L) & 152.5 \\
\hline & $\mathrm{pH}$ & 8.179 \\
\hline & $\mathrm{H}_{3} \mathrm{O}^{+}(\mathrm{mg} / \mathrm{L})$ & $6.6 \times 10^{-6}$ \\
\hline & $O H^{-}(\mathrm{mg} / \mathrm{L})$ & 0.02567 \\
\hline & $\mathrm{Cl}^{-}(\mathrm{mg} / \mathrm{L})$ & 18 \\
\hline & $\mathrm{SO}_{4}^{=}(\mathrm{mg} / \mathrm{L})$ & 62 \\
\hline & $\mathrm{HCO}_{3}^{-}(\mathrm{mg} / \mathrm{L})$ & 152.5 \\
\hline & $N a^{+}(\mathrm{mg} / \mathrm{L})$ & 75.6 \\
\hline & $K^{+}(\mathrm{mg} / \mathrm{L})$ & 6.8 \\
\hline & $\mathrm{Ca}^{2+}(\mathrm{mg} / \mathrm{L})$ & 38.4 \\
\hline & $M g^{2+}(\mathrm{mg} / \mathrm{L})$ & 14.6 \\
\hline \multirow[t]{5}{*}{ Physical } & Measured Temperature $\left({ }^{\circ} \mathrm{C}\right)$ & 36 \\
\hline & $\mathrm{Na}-\mathrm{K}$ geothermometer temperature $\left({ }^{\circ} \mathrm{C}\right)$ & 184.4 \\
\hline & $\mathrm{Na}-\mathrm{K}$-Ca geothermometer temperature $\left({ }^{\circ} \mathrm{C}\right)$ & 155.7 \\
\hline & Na-K-Ca corrected temperature $\left({ }^{\circ} \mathrm{C}\right)$ & 45.7 \\
\hline & $\mathrm{EC}(\mu \mathrm{S} / \mathrm{cm})$ & 610 \\
\hline
\end{tabular}

Table 1: Physical and chemical parameters of Lilida spring water.

\subsection{Geochemistry and geochemical facies of the Lilida Spring water}

The Lilida Spring water is characterized by a low electrical conductivity $(<1,700 \mu \mathrm{S} / \mathrm{cm})$, exactly $610 \mu \mathrm{S} / \mathrm{cm}$, which indicates a low mineralization confirmed by a low TDS (427 mg/L). Consequently, this water is classified as fresh water (TDS < $1000 \mathrm{mg} / \mathrm{L}$ ) (Glasser et al., 2007). This low salinity indicates that the water has circulated in non-saline fields.

An $8.179 \mathrm{pH}$ value explains the absence of carbonate ions $\left(\mathrm{CO}_{3}^{=}\right)$in this water. Thus, the bicarbonate ions $\left(\mathrm{HCO}_{3}^{-}\right)$, with a content of $152.5 \mathrm{mg} / \mathrm{l}$, determine alone the alkalinity. Bicarbonate (and carbonate) presents a serious hazard to equipment and structures because it is conducive to scaling phenomenon in presence of calcium and magnesium. Scaling may lead, among other things, to problems in items of industrial equipment, such as screens, vacuum pumps, heating baths, steam-heated drying drums and tanks. Scaling can also form on machines wires and felts, necessitating special cleaning procedures that can reduce their active life. With a capacity to depose $96 \mathrm{mg}$ of $\mathrm{CaCO}_{3}$ per liter of water, Lilida spring water has middle to moderate capacity to damage equipment and structures (due to scaling or precipitation), South African Department of Water Affairs and Forestry classification (1996). 
The Lilida Spring water sample is plotted in 4th field of the diagram of Piper (See figure 3), representing $\mathrm{Ca}-\mathrm{Na}-\mathrm{HCO}_{3}$ type, $\mathrm{Ca}-\mathrm{Na}$ dominant $\mathrm{HCO}_{3}$ type (or $\mathrm{HCO}_{3}$ dominant Ca-Na water type) with this following geochemical facies for the cations $\mathrm{Na}>\mathrm{Ca}>\mathrm{Mg}$ and this one for the anions: $\mathrm{HCO}_{3}>\mathrm{SO}_{4}>\mathrm{Cl}$.

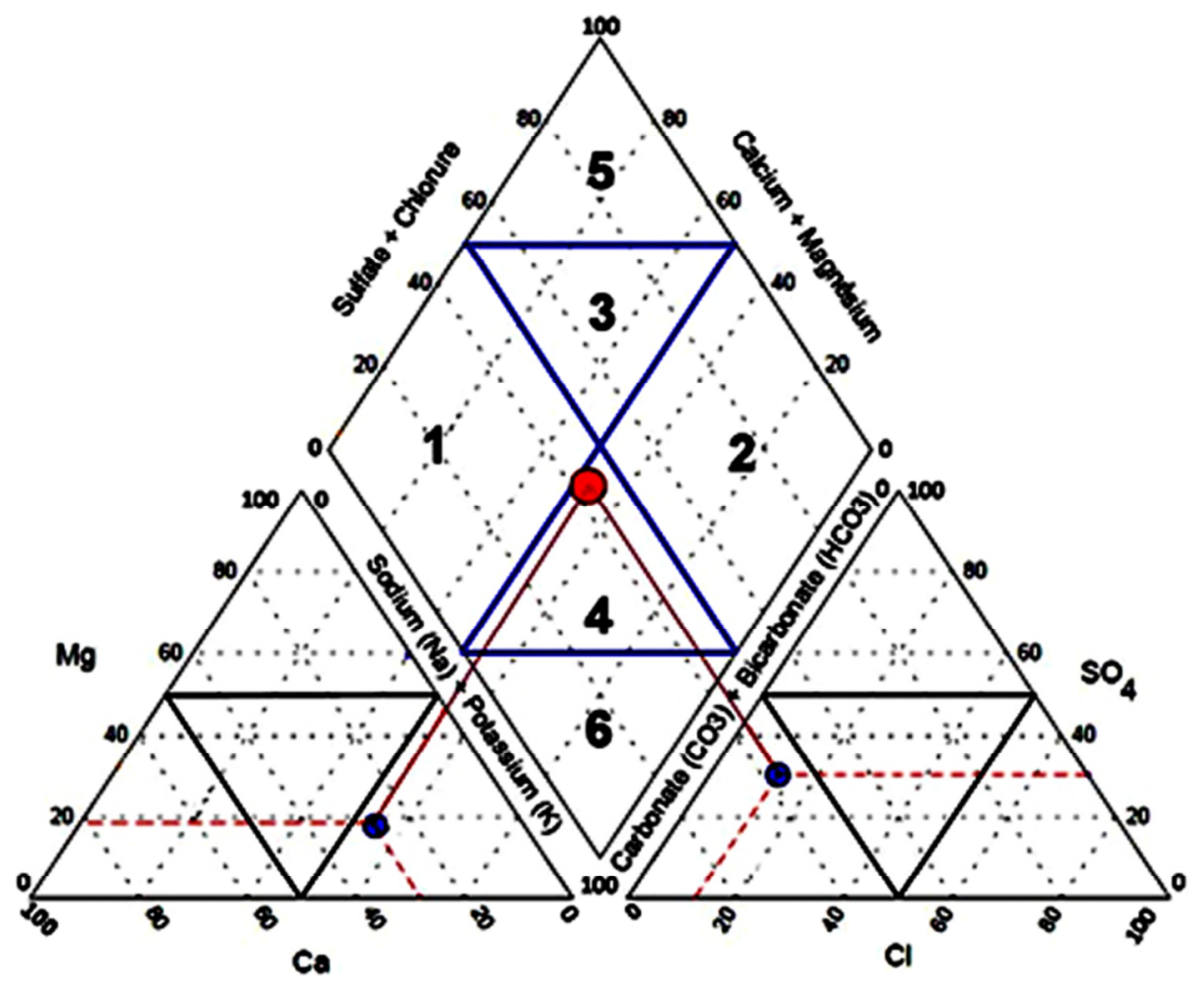

Fig. 3: Diagram of Piper applied to Lilida spring water.

From the Giggenbach ternary diagram (figure 4), the Lilida spring water plots in the region of peripheral water, corresponding to $\mathrm{HCO}_{3}{ }^{\circ}$ to rich and low chloride water illustrating that it is bicarbonate peripheral water. 


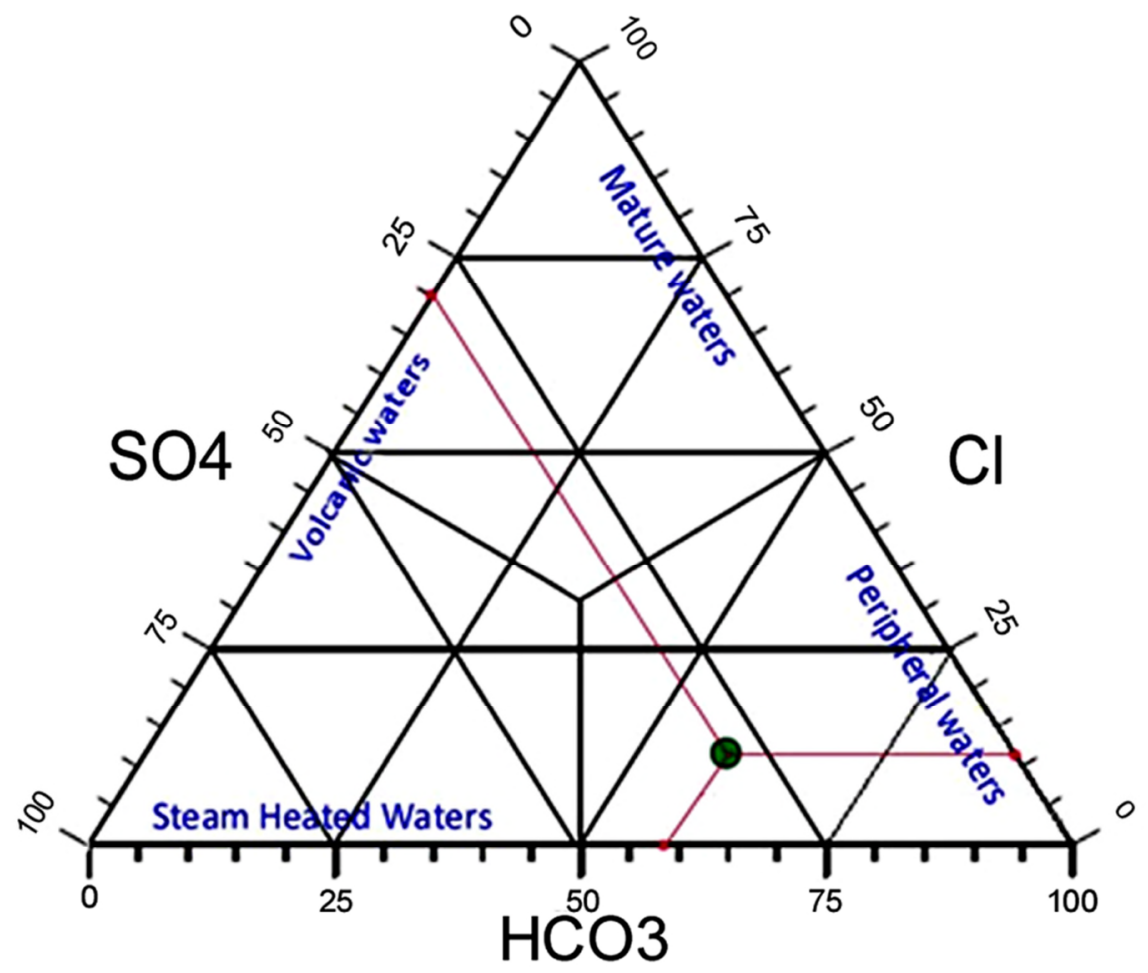

Fig. 4: Diagram of Giggenbach applied to Lilida spring water.

According to the classification of Giggenbach (1991), bicarbonate-rich waters are generally found in shallow aquifer. Consequently, the Lilida Spring water would be characterized as peripheral water. This is in keeping with the fact that limestone rocks are found in the superficial geological formation of Ituri (Woodtli, 1956). Although considered as the main source of carbonate ions in groundwater, the carbonate minerals dissolution is not their only one source everywhere. In volcanic regions, the dissolution of $\mathrm{CO}_{2}$ can be an important source of bicarbonate (Cinti et al., 2014). In relatively deep oxygen-poor ground waters, bicarbonate rich waters originate from either dissolution of $\mathrm{CO}_{2}$ or condensation of geothermal steam (Harsh \& Sukanta, 2007). Sometimes, the major origin of bicarbonate is the sewage systems (Kumar, 2013).

The dissociation of limestone occurs according to the following reaction:

$$
\mathrm{CaCO}_{3}+\mathrm{H}_{2} \mathrm{O} \rightarrow \mathrm{Ca}^{2+}+\mathrm{HCO}_{3}^{-}+\mathrm{OH}^{-}
$$

The ratio $\mathrm{HCO}_{3}^{-} / \mathrm{Ca}^{2+}$ equals 1 in this reaction; however, it is worth 2.6 in Lilida Spring water. It means that all ions $\mathrm{HCO}_{3}^{-}$are not from carbonate minerals dissociation. It is possible that a part of them originates from dissolution of $\mathrm{CO}_{2}$ from either a magmatic source or the atmosphere. Both sources are probable, because the Djugu Territory is located in the volcanic region of Albertine Rift and the Lilida Reservoir is shallow.

Chloride is a conservative ion in geothermal fluids: it does not take part in reactions with rocks after it has dissolved; it does not precipitate after it has dissolved and its concentration is independent of the mineral equilibrium that controls concentrations of rock-forming constituents (Skoog \& West, 1969). However, it is generally used in delineating the saline intrusions of saline water in an aquifer [18] and in classifying waters (Giggenbach, 1991; D'Amore et al., 1983). With a low chloride content and a high molar ratio $\mathrm{Na} / \mathrm{Cl}$ (exactly 6.5), Lilida spring water appears as having not undergone any saline water intrusion. Its high molar ratio $\mathrm{Na} / \mathrm{Cl}$ indicates also that it had not circulated in evaporative carbonated sequence or in plinth, while its low chloride content indicates that it had circulated in flyschs derivate (D'Amore et al., 1983).

The sulfate $\left(\mathrm{SO}_{4}\right)$ content of Lilida spring water was $62 \mathrm{mg} / \mathrm{L}$. The major origin of sulfate in water is the dissociation of gypsum, anhydrite (Kumar, 2013) or pyrite (Boudoukha \& Athamena, 2012). As the Ituri Province is auriferous, pyrite would be the most probable source of sulfate. 
The sodium $(\mathrm{Na})$ and potassium $(\mathrm{K})$ content of Lilida spring water were respectively 75.6 and 6.8 $\mathrm{mg} / \mathrm{L}$. All groundwater contains some sodium because most rocks and soils contain sodium compounds from which sodium is easily dissolved. The most common sources of sodium in groundwater are: erosion of salt deposits and sodium bearing rock minerals; naturally occurring brackish water of some aquifers; salt water intrusion into wells in coastal areas; infiltration of surface water contaminated by road salt; irrigation and precipitation leaching through soils high in sodium; groundwater pollution by sewage effluent; infiltration of leachate from landfills or industrial sites (British Columbia Groud Water Association, February 2007). Because Lilida Spring water does not undergo any saline water intrusion, and had not circulated in evaporative carbonated sequence or in plinth, we suggest that its sodium derived from erosion of sodium-bearing rock minerals, silicates minerals mainly. This is in keeping with the result of the graphic of D'Amore et al.(1983) applied to this study water (Figure 5), which indicates that it had circulated in argillaceous formation.

Calcium and magnesium contents in Lilida Spring water are respectively 38.4 and $14.6 \mathrm{mg} / \mathrm{L}$. In the normal groundwater systems, the main origin of these ions is carbonate minerals dissolution and depositional processes. Weathering of silicate minerals also contributes towards the enrichment of these minerals (Kumar, 2013). Suggestion of parameter D of the diagram of D'Amore et al.(1983) applied to study water (Figure 5) stipulating that this water has circulated in a dolomitic limestone, leads us to think that the major origin of calcium and magnesium is carbonate minerals. Low content of these elements $(<50 \mathrm{mg} / \mathrm{L})$ is a proof of a less pollution by surface waters (Alayat \& Lamouroux, 2007).

\subsection{Lithological nature of the Lilida spring reservoir}

The diagram of D'Amore et al. (1983) applied to study water (See figure 5 and 6) allows us to put forth the following readings:

- The parameter A indicates that the studied water had circulated through calcareous field rather than in evaporative sequence.

- The parameter B indicates that the studied water is enriched by sodium and circulated in sedimentary clayey-marly field.

- The parameter $\mathrm{C}$, very pronounced, testifies of a circulation in flyschs field by the studied water (because of its low chloride content).

- The parameter D indicates that the studied water had circulated in dolomitic limestone.

- The parameter E indicates the studied water had circulated in sulfated reservoir rather than in carbonated reservoir.

- The parameter $\mathrm{F}$ testifies in disfavor of a growth of potassium content in the studied water. Such observation excludes a possible circulation in granitic field.

Thus, this diagram, in spite of its resemblance with the standard plot $\gamma$ (Figure 6), adapts to reference diagram $\delta$ with a reduced parameter $\mathrm{D}$ and a pronounced parameter $\mathrm{C}$. It characterizes the Lilida Spring water as an argillaceous formation.

All those previous observations allow us to conclude that the Lilida Spring water had circulated in a shallow argillaceous formation containing probably dolomitic limestone and derivate of flyschs. 
Bulletin de la Société Royale des Sciences de Liège, Vol. 88, Articles, 2019, pp. 44 - 55

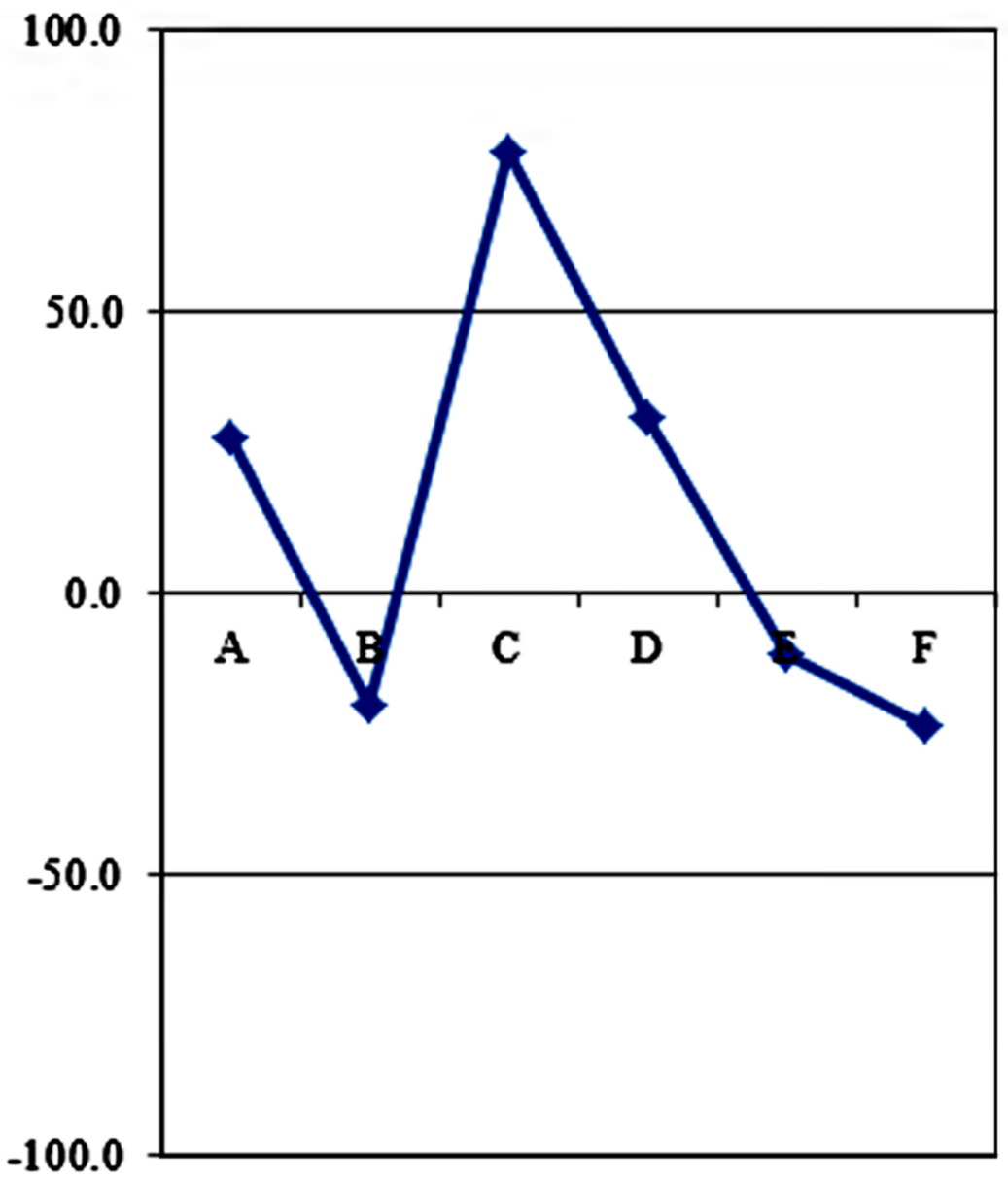

Fig. 5: The diagram of D'Amore et al. (1983) applied to Lilida spring water.
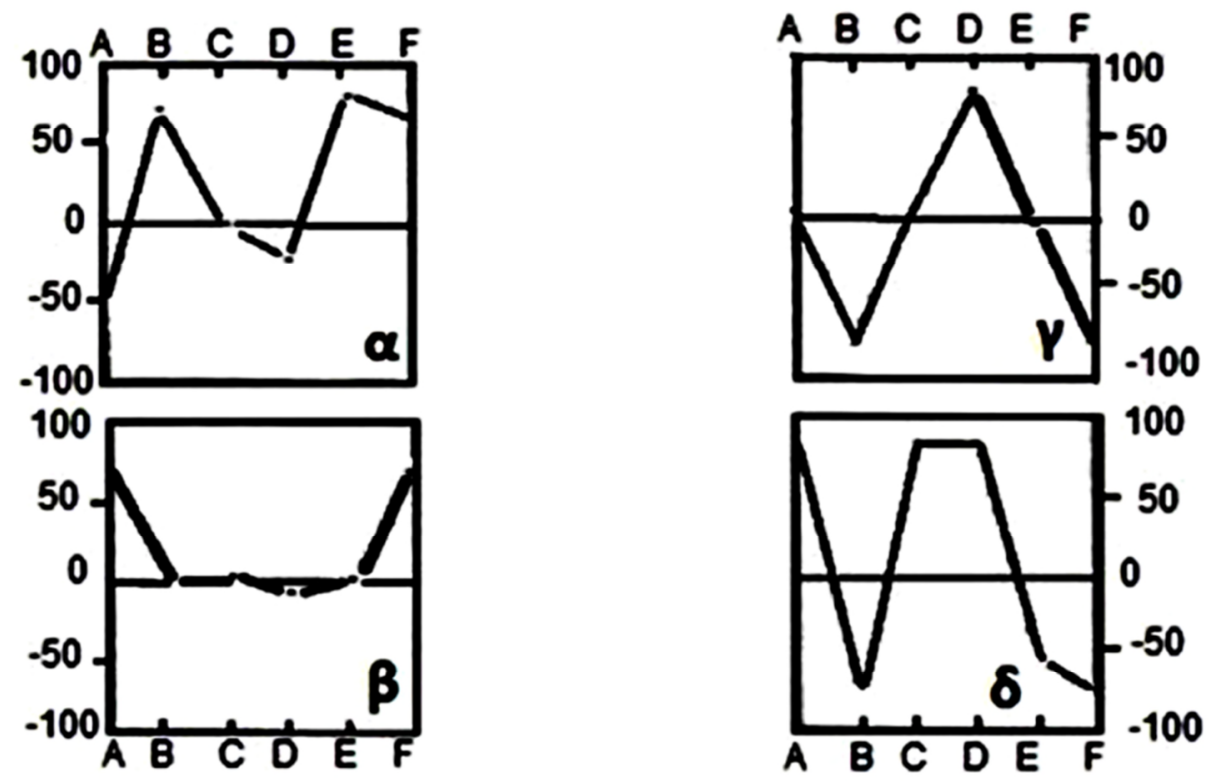

Fig. 6: Reference diagrams of D'Amore et al. (1983). $\alpha$ : evaporative sequence; $\beta$ circulation in limestone; $\gamma$ : deep circulation through a crystalline basement $; \delta$ : circulation in argillaceous formation. 


\subsection{The subsurface temperature of the Lilida Spring water}

The Lilida Spring water emerges with a temperature of $36^{\circ} \mathrm{C}$ classifying it in low enthalpy geothermal category. In this state, this thermal water can only be used for geothermal low energy exploitation; that is to say, for heating (of greenhouse, aquaculture ponds, house, etc.) mainly (Ahmed, 2009). Assessments from chemical Na-K geothermometer gave a temperature of $184.4{ }^{\circ} \mathrm{C}$. The Na-K thermometer based on a concentration ratio and working best for fluids whose temperature exceed $180^{\circ} \mathrm{C}$, is less affected by dilution and steam separation than other geothermometers, assuming that the diluting fluid contains little sodium or potassium. Also it is less affected by possible cooling due to the contact with deep rocks. Its main inconvenient is to suppose equilibrium reached while it is often not easy to demonstrate it (Fournier \& Truesdell, 1973). With the Na-K-Ca geothermometer, its correction, we obtained a temperature of $155.7^{\circ} \mathrm{C}$. Using of correction method formulated by Fournier and Potter II (Fournier \& Potter II, 1979) to correct Na-K-Ca geothermometer result, we obtained from the figure 2, $\mathrm{R}=36.73$ and $\Delta \mathrm{t}^{\circ}(\mathrm{Mg}) \approx 110^{\circ} \mathrm{C}$. Thus, the estimated subsurface temperature of Lilida Spring water was evaluated like this: $155.7{ }^{\circ} \mathrm{C}-110^{\circ} \mathrm{C} \approx 45.7^{\circ} \mathrm{C}$. Thus, we can confirm that in this state, this thermal water can only be used for geothermal low energy exploitation.

\section{Conclusion}

The Lilida Spring water is characterized as a bicarbonated calcosodic shallow fresh groundwater, with this following geochemical facies for the cations $\mathrm{Na}>\mathrm{Ca}>\mathrm{Mg}$ and this one for the anions: $\mathrm{HCO}_{3}>\mathrm{SO}_{4}>\mathrm{Cl}$.

The diagrams of Piper (1944), Giggenbach (1991) and D'Amore et al. (1983) applied on the water analyzes reveal that it had circulated in a shallow argillaceous field certainly containing dolomitic limestone and flyschs derivate.

Assessments from Na-K-Ca geothermometer and its correction on Lilida thermal water suggest the existence of a peripheral geothermal reservoir of low enthalpy $\left(45.7^{\circ} \mathrm{C}\right)$. Thus, in this state, this thermal water can only be used for geothermal low energy exploitation.

\section{References}

Ahmed, F. A. (2009). Intégration des énergies rénouvelables pour une politique énergétique durable à Djibouti. Thèse de Doctorat: Université de Corse. 178pp.

Alayat, H., \& Lamouroux, C. (2007). Caractérisation physico-chimique des eaux thermominerales des Monts de la Cheffia. Geo. Eco. Mar, 13:75-84.

Boudoukha, A., \& Athamena, M. (2012). Caractérisation des eaux thermales de l'ensemble Sud sétifien. Est algérien. Rev. Sci. Eau, 25 (2):103-119.DOI : 10.7202/1011602ar.

British Columbia Groud Water Association. (February 2007). Sodium in Groundwater. British Columbia: Water Stewardship Information. 2pp.

Cinti, D., Tassi, F., Procesi, M., Bonini, M., Capecchiacci, F., Voltattorni, N., et al. (2014). Fluid geochemistry and geothermometry in the unexploited geothermal field of the Vicano-Cimino Volcanic District (Central Italy). Chem. Geol, 371: 96-114.

D'Amore, F., Scandifio, \& Panichi, C. (1983). Some Observation on the Chemical Classification of Ground Waters. Geothermics, 12:141 - 148.

Esseqqat, H. (2011). Les énergies rénouvelables en République démocratique du Congo. PNUE. 101pp.

Fournier, R. O., \& Potter II, R. W. (1979). Magnesium Correction to the Na-K-Ca Chemical Geothermometer. Geochem. Cosmochim. Acta, 43: 1543-1550.

Fournier, R. O., \& Truesdell, A. H. (1973). An empirical Na-K-Ca geothepmometer for natural waters. Geochim. Cosmochim. Acta, 37:1255-1275. 
Giggenbach, W. F. (1991). Chemical techniques in geothermal exploration. In: Application of geochemistry in geothermal reservoir development. D'Amore, $F$. UNITAR/UNDP publication, Rome. pp.119-142.

Glasser, S., Gauthier-Warinner, J., Gurrieri, J., Keely, J., Tucci, P., Summers, P., et al. (2007). Technical Guide to Managing Ground Water Resources. USDA. 281pp.

Harsh, G., \& Sukanta, R. (2007). Geothermal energy: An alternative resource for the 21st century. Elsevier B.V. ISBN-13:9978-0-444-5287-9, ISBN-10: 0-444-52875-X. 293pp.

Kumar, S. (2013). Interpretation of groundwater chemistry using piper and chadha's diagrams: a comparative study from perambalur taluk. Elixi. Geosci, 54 (2013):12208-12211.

Michard, G. (1979). Géothermomètres chimiques. Bull. BRGM section III $n^{\circ}$ 2, 183-189.

Ndjele, M.-B. (1988). Les éléments phytogéographiques endémiques dans la flore vasculaire du Zaïre. Thèse de doctorat: Université Libre de Bruxelles. 528 pages.

Ring, U. (2014). The East African Rift System, . Aus. J. Earth. Sci, 117 : 132-146.

Skoog, D. A., \& West, D. M. (1969). Fundamentals of Analytical Chemistry. 2nd Edition. Holt, Rienehart \& Wiston Ed. ISBN: 003910129 0. 835pp.

South African Department of Water Affairs and Forestry. (1996). South African Water Quality Guidelines. Volume 3: Industrial use. Second edition. Prétoria: South African WQG. 108 pp.

Sys, C. (1960). Notice explicative de la carte de sols du Congo belge et du Ruanda-Urundi. INEAC, 1302: 41-46.

Woodtli, R. (1956). La structure de Kilo: contribution à l'étude des fossés africains. Bruxelles: Mém. Acad. Roy. Sci. Col. Belg., Cl. Sci. Tech. Mémoires ln- $8^{\circ}$. Nouvelle série.Tome VI, f asc. 2. $116 p$. 